\title{
Território e Desenvolvimento: as múltiplas escalas entre o local e o global
}

\section{Glauco da Costa Knopp ${ }^{1}$}

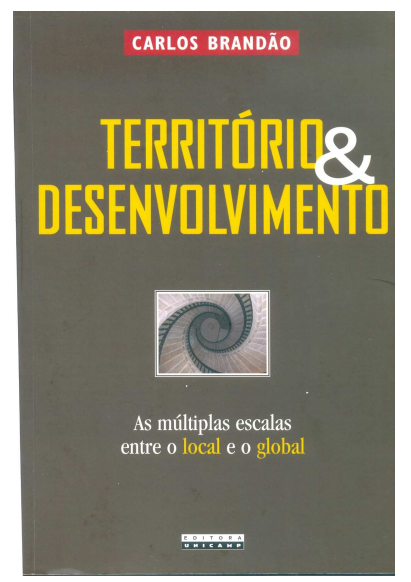

BRANDÃO, Carlos. Território e Desenvolvimento: as múltiplas escalas en-

tre o local e o global. São Paulo: Editora da Unicamp, 2007.

As transformações ocorridas no Brasil nos anos 1980 e 1990, tais como o processo de redemocratização do país, a descentralização fiscal e o reconhecimento dos municípios como entes federativos, a partir da Constituição Federal de 1988, aliadas ao aumento das desigualdades estruturais internas nas diversas porções do território nacional fazem emergir novas formas de pensar e agir no campo das políticas públicas.

Nesse contexto, e como reflexo dele, as políticas públicas, especialmente aquelas destinadas à promoção do desenvolvimento, outrora caracterizadas pelo centralismo financeiro e decisório no plano federal, passaram a ser mais descentralizadas, ou seja, deixaram de ser formuladas de cima para baixo, com base no planejamento nacional, e passaram a se originar nos planos regional e local. Isto implica dizer que o enfoque sobre a dimensão territorial ou escala espacial para a concepção e implementação de políticas e programas de desenvolvimento passa, principalmente, para o plano local.

Se por um lado houve a revalorização do território e da dimensão espacial do desenvolvimento, notadamente a local, por outro parece ter se consolidado uma visão cega, uma espécie de romantismo ou "pensamento único localista" (p. 36). Verifica-se, assim, uma concepção do local como espaço privilegiado de intervenção política para a solução de todas as mazelas socioeconômicas, em detrimento das demais escalas territoriais. É como se o local tudo pudesse, "dependendo de sua vontade de auto-impulso" (p. 39) para promover um virtuoso processo desenvolvimento.

À concepção localista sobre o desenvolvimento complementam-se as idéias de inserção dos espaços locais ao espaço econômico global, engendrando a polarização local-global desse processo. Nessa lógica, as escalas intermediárias entre o local e o global - microrregional, mesorregional, macrorregional e nacional - são desconsideradas ou perdem importância na articulação para a promoção do desenvolvimento.

Recorrendo à história - e interrogando-a, conforme defendia Celso Furtado - para compreender a formação espacial brasileira, as heterogeneidades e vulnerabilidades estruturais e o processo que fez do Brasil um país subdesenvolvido, Brandão afirma que o país só sairá dessa condição de malformação estrutural a partir da construção de uma política nacional de desenvolvimento, apontando, ainda, para as limitações das abordagens excessivamente localistas e endogenistas para esse fim. Faz-se necessário reconstruir a escala nacional, elaborando,

${ }^{1}$ Mestre em Administração Pública pela Escola Brasileira de Administração Pública e de Empresas da Fundação Getulio Vargas (EBAPE/FGV). Bacharel em Administração de Empresas com ênfase em Marketing pela Escola Superior de Propaganda e Marketing (ESPM). Pesquisador do Grupo de Pesquisa Observatório da Realidade Organizacional. Coordenador de Monitoramento e Avaliação do PNAGE - Secretaria de Planejamento e Gestão do Estado do Rio de Janeiro. 
contudo, políticas públicas e ações transversais nas demais escalas, que deverão ser devidamente articuladas e integradas pelo Estado para a efetivação de um projeto de desenvolvimento, levando-se em consideração as peculiaridades de cada porção do território brasileiro, a diversidade e as assimetrias existentes entre elas.

Nesse sentido, Brandão propõe uma abordagem transescalar do desenvolvimento, que pode ser concretizada, na prática, por meio da consolidação de um novo pacto federativo entre os níveis de governo. Assim, busca-se "articular horizontalmente os atores institucionais de uma mesma região e integrar verticalmente as diferentes escalas político-administrativas" (p. 209), de forma que viabilize "modos de pensar e agir capazes de produzir efetivas transformações das estruturas sociais, em todas as escalas" (GOULART, VIEIRA E CARVALHO, 2005, p. 70).

O maior desafio das políticas públicas nacionais de desenvolvimento parece ser, portanto, consolidar a "descentralização coordenada", considerando as múltiplas escalas e evitando a atomização das ações (BACELAR, 2006), pautando-se numa "combinação de relações geográficas verticais e horizontais" (SAQUET, 2007, p. 112) para alargar os horizontes de possibilidades dos cidadãos brasileiros, promover inclusão social, reduzir as desigualdades estruturais internas, ativar as potencialidades da diversidade social, econômica e cultural do território e reduzir o grau de dependência externa do país.

É preciso, portanto, um novo modelo de desenvolvimento nacional, considerando e trabalhando conjuntamente e de forma articulada as escalas local, microrregional, marcrorregional e nacional, que nas últimas décadas vêm sendo esquecidas pela literatura e pelos formuladores de políticas públicas, sem, contudo, perder de vista a integração do país à escala global. Essa parece ser a melhor maneira, segundo Brandão, de darmos continuidade à construção do Brasil, que há muito tempo foi interrompida, para que assim tenhamos um novo e promissor amanhecer.

Carlos Brandão, por meio de sua obra, aponta para a possibilidade de um verdadeiro projeto de nação, a partir da discussão sobre território e das potencialidades da formulação de uma política pública nacional de desenvolvimento. O livro constitui-se em uma referência indispensável para alunos e pesquisadores de Administração Pública, bem como para os formuladores de políticas públicas brasileiros.

\section{Referências}

BACELAR, Tânia. Desenvolvimento regional: a descentralização valorizaria a diversidade. In: FLEURY, S. (Org.). Democracia, descentralização e desenvolvimento: Brasil \&t Espanha. Rio de Janeiro: Editora FGV, 2006.

GOULART, Sueli; VIEIRA, Marcelo M. F.; CARVALHO, Cristina A. Universidades e desenvolvimento local: uma abordagem institucional. Porto Alegre: Sagra Luzzatto, 2005.

SAQUET, M. A. Abordagens e concepções sobre território. São Paulo: Expressão Popular, 2007. 